\title{
Prolificity of strawberry genotypes in subtropical climate
}

\author{
Prolificidad de genotipos de frutilla en clima subtropical \\ Cipriano Ramón Enciso-Garay ${ }^{1}$, Victoria Rossmary Santacruz Oviedo ${ }^{1}$, \\ Diego Garcia ${ }^{1}$ and Oscar Guillén ${ }^{2}$
}

\begin{abstract}
This work evaluated the potential production and quality of daughter plants of 20 strawberry genotypes produced in containers in a protected environment. The experimental design used was randomized complete blocks with three repetitions. It was evaluated: number of daughter plants produced per mother plant, number of leaves, leaf area, root length, crown diameter, fresh, and dry mass of the aerial part and the root system. Data were subjected to analysis of variance, and means were compared by Tukey test at a $5 \%$ probability. Cultivars responded differently in the production of daughter plants, number of leaves, fresh and dry mass of the aerial part and the root system. The results showed that the Dover $x$ Esplendida genotype presented the largest number of daughter plants, while Sabrina had the highest fresh and dry mass of the aerial part and fresh mass of the root system. Sweet Charlie FP and Sabrina stood out for the high dry matter content of the root system. There were no differences in the variables leaf area, root length, and crown diameter. The daughter plants produced by the evaluated genotypes presented the minimum requirements in terms of the number of leaves and crown diameter.
\end{abstract}

Key words: Fragaria $x$ ananassa Duch, propagation, cultivars, stolons.

\section{RESUMEN}

Este trabajo fue realizado con el objetivo de evaluar el potencial de producción y calidad de plantas hijas de 20 genotipos de frutilla producidas en contenedores en ambiente protegido. El diseño experimental utilizado fue de bloques completos al azar con tres repeticiones. Se evaluaron: número de plantas hijas producidas por planta madre, número de hojas, área foliar, longitud de raíz, diámetro de corona, masa fresca y seca de la parte aérea y del sistema radicular. Los datos fueron sometidos al análisis de varianza y a la comparación de medias por la prueba de Tukey al $5 \%$ de probabilidad. Los cultivares respondieron en forma diferenciada en la producción de plantas hijas, número de hojas, masa fresca y seca de la parte aérea y del sistema radicular. Los resultados mostraron que el genotipo Dover x Esplendida presentó el mayor número de plantas hijas, mientras que Sabrina la mayor masa fresca y seca de la parte aérea y, masa fresca del sistema radicular. Sweet Charlie FP y Sabrina se destacaron por el elevado contenido en materia seca del sistema radicular. No se encontraron diferencias en las variables área foliar, longitud de raíz y diámetro de corona. Las plantas hijas producidas por los genotipos evaluados presentaron los requisitos mínimos exigidos en cuanto a número de hojas y diámetro de corona.

Palabras clave: Fragaria x ananassa Duch, propagación, cultivar, estolones.

\section{Introduction}

The strawberry (Fragaria x ananassa Duch) due to the beauty of its fruits, its sweetness, aroma, its healthy character, and the possibility of consumption both fresh and processed and is grown on all continents. World production is $8,377,099$ tons per year; the most prominent producers are China, United States, Mexico, Spain, and, France. In South America, the biggest producer is Chile, followed by Argentina and Brazil (FAO, 2018).
Mainly family producers settled in peri-urban areas, most of them are smallholders or tenants carry out the cultivation of strawberries in Paraguay, where they use family labor throughout the cycle, and for that reason, it constitutes an essential source of income for these families.

Strawberry propagation can be both sexually and asexually. Genetic improvement programs use sexual route through seeds to obtain new varieties due to the genetic variability that it presents (Cocco et al., 2016). Vegetative propagation through

\footnotetext{
1 Faculty of Agricultural Sciences, National University of Asuncion. San Lorenzo, Paraguay.

2 Paraguayan Institute of Agricultural Technology. Caacupé. Paraguay.

* Corresponding author: cipriano.enciso@gmail.com
}

Fecha de Recepción: 20 de Febrero, 2020.

Fecha de Aceptación: 2 de Abril, 2020. 
stolons is the most used by producers because they have the same characteristics as the mother plant as they are clones. Its fertile knot quickly emits adventitious roots, and its terminal bud forms leaves, axillary buds, and a crown that will constitute the new plant (Silva et al., 2007). The photoperiod is the main factor responsible for the transition from the reproductive to the vegetative phase (Massetani et al., 2011). Long days and high temperatures favor the vegetative development of the strawberry, stimulating stolon emission, and inhibiting flowering (Serce and Hancock, 2005). Ishijima and Okawara (2002) mention that for the conditions of Paraguay, temperatures above $20^{\circ} \mathrm{C}$ and a photoperiod greater than 13 hours of light allow the emission of stolons.

In Paraguay, due to its subtropical climate and low altitude, there are no conditions for the production of the so-called "frigo" plants. For that reason and unlike other countries, for commercial propagation, producers acquire the in vitro culture of the mother plants from specialized laboratories and take it to the field for the daughter's plants production with bare roots. In addition, they transplant it in containers loaded with substrate that after being placed on countertops under a greenhouse or vegetation house where the emitted stolons are transferred to containers for rooting. These stolons remain attached to the mother plant until the moment of transplantation to the final place.

The recommended time of transplant of the mother plants in Paraguay goes from mid-October to the end of November, and the ideal daughter plants to be transplanted must be 60 to 70 days old (Ishijima and Okawara, 2002).

Daughter plants of strawberry produced in containers in height are of higher physiological quality, which allows reducing the use of agricultural defenses by the lower incidence of diseases caused by soil fungi, facilitates the transplantation, increases the percentage of survival in the field after transplanting, allows to advance the time of transplantation and consequently the early production of fruits (Durner et al., 2002, Ishijima and Okawara, 2002, Verdial et al., 2009, Hochmuth et al., 2006).

The daughter plant is one of the primary inputs of the strawberry production system. It is directly related to productivity and quality, being the starting point for obtaining a higher level of response to any technology used in the process production of the strawberry (Oliveira and Scivittaro, 2009; Oliveira et al., 2007).

The most widespread strawberry cultivars in Paraguay are of short photoperiod, mainly of American origins, such as Dover, Camarosa and Sweet Charlie, however, in recent years through crossings made in the country have been obtained promising lines that need to be evaluated in relation to its ability to emit stolons, before being released to producers. In the country, there is no information about the potential for production and quality of daughter plants of strawberry genotypes in containers, for which reason is necessary to generate knowledge that allows producers to have a better planning of their production.

The objective of this work was to evaluate the potential's propagation and quality of daughter plants produced in containers with soil lumps by strawberry genotypes, in subtropical weather conditions.

\section{Materials and methods}

The experiment was between December 2014 and March 2015 inside a greenhouse covered with low-density polyethylene with UV additive protector, 150 micron's thick. It was developed at Centro de Investigación "Hernando Bertoni" (CIHB), dependent of the Instituto Paraguayo de Tecnología Agraria (IPTA), situated on the township of Caacupé, Cordillera Department, Paraguay, located between las coordinates $25^{\circ} 23^{\prime} 16.38^{\prime \prime}$ latitude South, $57^{\circ} 11^{\prime} 22.24^{\prime \prime}$ West longitude and 228 masl.

The climate is humid subtropical, with an annual average of $22{ }^{\circ} \mathrm{C}$ and precipitation of $1,532 \mathrm{~mm}$. Table 1 shows the maximum average and minimum temperature during the experiment's execution time. The photoperiod ranges between 10.6 hours of light in June and 13.7 hours of light in December.

Twenty genotypes were evaluated consisting of 13 cultivars of strawberry (Sabrina, Rosalinda, Camino Real, Festival, Florida Eliane, Sweet Charlie, Sweet Charlie FP (from a producer farm), Dover, Esplendida, IAC Guarani, Yeobang, Corea and Early Bright) and seven CIHB hybrid clones (Dover x Rosalinda (1), Dover x Rosalinda (4), Dover x R2 (63), Dover x Aichi 510-28, Dover $x$ Esplendida, Dover x Aichi and Dover x Aichi 
Table 1. Average mínimum and maximum temperature monthly during the period of obtaining daugther plants of strawberry genotype. Caacupé, Paraguay.

\begin{tabular}{lcc}
\hline & \multicolumn{2}{c}{ Temperature } \\
\cline { 2 - 3 } Monthly/year & $\begin{array}{c}\text { Minimum average } \\
\left({ }^{\circ} \mathrm{C}\right)\end{array}$ & $\begin{array}{c}\text { Maximum average } \\
\left({ }^{\circ} \mathrm{C}\right)\end{array}$ \\
\hline December/2014 & 25.5 & 30.8 \\
January/2015 & 26.5 & 32.6 \\
February/2015 & 26.5 & 31.5 \\
March/2015 & 25.5 & 31.8 \\
\hline
\end{tabular}

19), classified as short day. The Biotechnology Laboratory of the CIHB provided the mother plants. The experimental design used was the randomized complete blocks with three repetitions, where a mother plant represented each experimental unit.

The mother plants were transplanted on $12 / 01 / 2014$ on plastic bags of $5 \mathrm{~L}$, containing substrate constituted of bovine manure and agricultural soil in a 1:1 ratio, previously sterilized. After the transplanting, the plastic bags were placed on countertops located at $1 \mathrm{~m}$ of height from the floor, with $0.5 \mathrm{~m}$ separation between them. Eight days after the transplant was applied $5 \mathrm{~g}$ of chemical fertilization with the formulation 15-15-15 (N-P-K), for each bag, every 15 days, according to the recommendation of Ishijima and Okawara (2002). During the conduct of the experiment, the flowers and old leaves of the mother plants were periodically removed.

As the mother plants emitted the stolons, the same were rooted in plastic bags of $250 \mathrm{~cm}^{3}$, loaded with the same substrate mentioned above. These plastic bags with rooted stolons were also kept in height above countertops to avoid contact with the ground. The irrigation was daily by spraying, and the pest and diseases control according to the plant's needs.

The evaluations were 110 days after the transplantation of mother plants and were the following: number of daughter plants viable emitted by the mother plant, considering as viable daughter plants those that presented at least three leaves fully developed (Ishijima and Okawara, 2002). Of the daughter plant, produced seven plants were selected randomly per genotype and repetition, which were quantified:

- Number of leaves per daughter plant: the fully expanded leaves were counted.
- Root length (cm): it measured with a centimeter ruler from the base of the crown until the tip of the longest root.

- Crown diameter $(\mathrm{cm})$ : it measured with a digital Vernier calibrator.

Aerial part's dry mass (g): the aerial part (leaves and crown) was separated from the radicular system, washed and dried in an oven at $65^{\circ} \mathrm{C}$ for 72 hours, and subsequently weighed on a digital electronic scale.

Root system's dry mass (g): the root system it was separated from the aerial part, washed and dried in an oven at $65^{\circ} \mathrm{C}$ for 72 hours and subsequently weighed on a digital electronic scale.

Foliar area $\left(\mathrm{cm}^{2}\right)$ : the leaves of the daughter plants were separated, and the foliar area was measured (YMJ-C digital leaf area meter).

Data were subjected to analysis of variance and the variables with statistical differences to mean comparison by Tukey test at $5 \%$ of probability error.

\section{Results and discussion}

The number of daughter plants produced per mother plant (Table 2) presented significant statistical differences between genotypes. Dover x Esplendida produced on average 207 daughter plants, differing statistically from Sabrina, Rosalinda, Camino Real, Festival, Sweet Charlie, Sweet Charlie FP, Dover, Esplendida, IAC Guaraní, Yeobang, Early Bright, Dover x Aichi 510-28 and Dover x Aichi 19, but did not differ from the other genotypes evaluated. Authors such as Oliveira et al., (2007), Tessarioli Neto et al., (2003), also reported the differentiated effect of genotypes on the strawberry propagation rate Bueno (2006), Rodríguez - Bautista et al., (2012) and Dias et al., (2014). The number of daughter plants obtained in this investigation with Dover (98), Sweet Charlie (56) and Sweet Charlie FP (85) is higher to the reported by Oliveira et al., (2007) it obtained 34 daughter plants with Dover 34 and 30.7 daughter plants with Sweet Charlie, respectively. Likewise, Festival generated 97 daughter plants, which is higher than the average of 68.40 daughter plants reported by RodríguezBautista et al., (2012), also using the production system of daughter plants in containers. On the other hand, Dias et al., (2014), in his investigation with the cultivar of strawberry Festival and Camino 
Table 2. Number of daughter plants (NDP), number of leaves per daughter plant (NLDP), leaf area (LA), root length (RL), and crown diameter (CD) of 20 strawberry genotypes. Caacupé. Paraguay.

\begin{tabular}{|c|c|c|c|c|c|}
\hline Genotypes & NDP & NLDP & $\mathrm{LA}\left(\mathrm{cm}^{2}\right)$ & $\mathrm{RL}(\mathrm{cm})$ & $\mathrm{CD}(\mathrm{mm})$ \\
\hline Sabrina & $36 \mathrm{c}$ & $6.60 \mathrm{abc}$ & $33.70 \mathrm{~ns}$ & $14.00^{\mathrm{ns}}$ & $11.40^{\mathrm{ns}}$ \\
\hline Rosalinda & $67 \mathrm{bc}$ & $5.60 \mathrm{abc}$ & 25.70 & 14.00 & 12.00 \\
\hline Camino Real & $76 \mathrm{bc}$ & $5.25 \mathrm{abc}$ & 23.90 & 11.14 & 10.55 \\
\hline Festival & $97 \mathrm{bc}$ & $4.30 \mathrm{c}$ & 26.45 & 13.65 & 10.65 \\
\hline Florida Eliane & $130 \mathrm{abc}$ & $6.30 \mathrm{abc}$ & 34.35 & 12.20 & 10.95 \\
\hline Sweet Charlie & $56 \mathrm{bc}$ & $4.95 \mathrm{bc}$ & 23.15 & 12.90 & 10.00 \\
\hline Sweet Charlie FP & $85 \mathrm{bc}$ & $7.65 \mathrm{a}$ & 32.00 & 12.65 & 12.50 \\
\hline Dover & $98 \mathrm{bc}$ & $7.00 \mathrm{ab}$ & 24.60 & 12.85 & 11.05 \\
\hline Esplendida & $34 \mathrm{c}$ & $5.55 \mathrm{abc}$ & 30.15 & 13.35 & 9.70 \\
\hline IAC Guaraní & $66 \mathrm{bc}$ & $5.20 \mathrm{bc}$ & 27.90 & 12.15 & 11.05 \\
\hline Yeobang & $58 \mathrm{bc}$ & $5.60 \mathrm{abc}$ & 24.45 & 12.95 & 9.15 \\
\hline Corea & $121 \mathrm{abc}$ & $7.00 \mathrm{ab}$ & 24.15 & 11.05 & 10.70 \\
\hline Early Bright & $52 \mathrm{c}$ & $6.30 \mathrm{abc}$ & 30.40 & 13.35 & 12.35 \\
\hline Dover x Rosalinda (1) & $158 \mathrm{ab}$ & $5.45 \mathrm{abc}$ & 21.80 & 12.60 & 9.70 \\
\hline Dover x Rosalinda (4) & $160 a b$ & $6.85 \mathrm{ab}$ & 22.85 & 12.95 & 10.75 \\
\hline Dover x R2 (63) & $136 \mathrm{abc}$ & $7.35 \mathrm{ab}$ & 24.45 & 12.95 & 11.10 \\
\hline Dover x Aichi 510-28 & $88 \mathrm{bc}$ & $5.90 \mathrm{abc}$ & 24.20 & 12.25 & 11.85 \\
\hline Dover x Esplendida & $207 \mathrm{a}$ & $5.80 \mathrm{abc}$ & 21.30 & 10.70 & 9.60 \\
\hline Dover x Aichi & $126 \mathrm{abc}$ & $7.15 \mathrm{ab}$ & 21.35 & 11.90 & 11.40 \\
\hline Dover x Aichi 19 & $87 \mathrm{bc}$ & $5.75 \mathrm{abc}$ & 26.30 & 12.00 & 11.35 \\
\hline C.V. $(\%)$ & 26.76 & 9.77 & 15.12 & 10.16 & 8.71 \\
\hline
\end{tabular}

$\mathrm{NDP}=$ number of daughter plants; NLDP = number of leaves per daughter plant; $\mathrm{LA}=$ leaf area; $\mathrm{RL}=$ root length; $\mathrm{CD}=$ crown diameter.

ns $=$ not significant at $5 \%$ probability of error.

*Means followed by the same letter in the column do not differ from each other by the Tukey test at $5 \%$ probability of error.

Real obtained 294.25 and 149.50 daughter plants, respectively, which are remarkably higher than the means obtained in this experiment for the same cultivars. The results obtained in the daughter plant emissions indicate that there are genetic differences between the sensibility to climatic factors, such as temperature, photoperiod, and light intensity, and crop management (Oliveira et al., 2010). The propagation potential of a cultivar is one of the most relevant requirements considered in a program of genetic improvement of strawberry (Oliveira et al., 2007).

Concerning the number of leaves per daughter plant (Table 2), the Sweet Charlie FP genotype presented the highest average (7.65 leaves), statistically differing from Festival (4.30 leaves), IAC Guaraní (5.20 leaves) and Sweet Charlie (4.95 leaves), which presented the lowest means and did not differ from each other. Gonçalves et al., (2012), in his investigation, had found that the daughter plants of the Festival cultivar issued an average of 5.60 leaves, close to that obtained in this investigation. The results achieved in this work indicate that all daughter plants produced by the evaluated genotypes presented the minimum requirement of 3 to 4 leaves, at the time of transplantation, according to Ishijima and Okawara (2002). The number of leaves at the time of transplantation is a critical feature because they are the responsible organs for photosynthesis and photo-assimilates production that are subsequently translocated to the fruits.

For the variable foliar area of daughter plants (Table 2) did not find significant statistical differences, with the mean varying between 33.70 $\mathrm{cm}^{2}$ (Sabrina) and $21.30 \mathrm{~cm}^{2}$ (Dover x Esplendida). These results indicate that the plants with the highest number of leaves do not always have a greater leaf area. In this investigation, Sweet Charlie FP presented the highest number of leaves. However, there were no differences between genotypes in the leaf area; this may be due to the leaf size is a genetic characteristic, therefore, not always the plant with the highest number of leaves have greater leaf area. Rosa et al., (2013) found morphological differences in the leaves of strawberry cultivar Yvapytá and Arazá, where the first always presented larger leaves. The leaf 
area is a relevant characteristic; this is because is related to the interception of solar radiation and the photosynthetic activity of the leaf, for carbohydrate synthesis, used for plant growth and development (Cordeiro et al., 2019).

There were no significant statistical differences between genotypes for root length (Table 2), which was between $14 \mathrm{~cm}$ (Sabrina and Rosalinda) and $10.70 \mathrm{~cm}$ (Dover x Esplendida). This result differs from that reported by Oliveira et al. (2007), who, when evaluating ten strawberry cultivars, found significant statistical differences in the length of root, with averages between $2.3 \mathrm{~cm}$ (Camarosa) and $6.3 \mathrm{~cm}$ (Aromas). Bartezak et al., (2010) mention that there is a positive correlation between the length of root and strawberry yield.

The crown diameter of daughter plants did not present statistical differences (Table 2), varying between $12.50 \mathrm{~mm}$ (Sweet Charlie FP) and $9.60 \mathrm{~mm}$ (Dover x Esplendida). Gonçalves et al., (2012) reported that the Festival cultivar produced daughter plants with a crown diameter of $8.94 \mathrm{~mm}$, lower than the average of $10.65 \mathrm{~mm}$ obtained for the same cultivation in this research. According to Durner et al., (2002), one of the criteria to determine the physiological quality of daughter plants is the crown diameter that must be greater than $8 \mathrm{~mm}$, used in commercial plantations. According to these results, all daughter plants produced by the different genotypes can be used for commercial planting. Cocco et al., (2010) mention that daughter plants with greater crown diameter are more vigorous in the field, with higher vegetative growth and early fruit production, but without effect on the yield. Menzel and Smith, (2012) in research using crowns of 6 to $10 \mathrm{~mm}$ and 10 to $17 \mathrm{~mm}$ for Festival cultivar and crowns of de 5 to $8 \mathrm{~mm}$ and 10 to $17 \mathrm{~mm}$ for Florida Fortuna cultivar, transplanted in three seasons, reported that in all cases the daughter plants with the highest crown diameter had a higher fruit yield.

The fresh mass of the aerial part and the root system (Table 3) presented significant statistical differences between genotypes, obtaining for both

Table 3. Fresh mass of the aerial part (FMA), fresh mass of the root system (FMRS), dry mass of the aerial part (DMAP), and dry mass of root system (DMRS) of 20 strawberry genotypes. Caacupé, Paraguay.

\begin{tabular}{lcccc}
\hline \multicolumn{1}{c}{ Genotypes } & FMA $(\mathrm{g})$ & FMRS $(\mathrm{g})$ & DMAP $(\mathrm{g})$ & DMRS $(\mathrm{g})$ \\
\hline Sabrina & $22.40 \mathrm{a}$ & $6.00 \mathrm{a}$ & $12.70 \mathrm{a}$ & $3.20 \mathrm{ab}$ \\
Rosalinda & $18.70 \mathrm{ab}$ & $3.80 \mathrm{ab}$ & $12.70 \mathrm{a}$ & $2.00 \mathrm{ab}$ \\
Camino Real & $10.85 \mathrm{~b}$ & $2.5 \mathrm{ab}$ & $7.50 \mathrm{abc}$ & $1.25 \mathrm{ab}$ \\
Festival & $16.75 \mathrm{ab}$ & $3.75 \mathrm{ab}$ & $7.70 \mathrm{abc}$ & $2.10 \mathrm{ab}$ \\
Florida Eliane & $16.35 \mathrm{ab}$ & $4.10 \mathrm{ab}$ & $10.70 \mathrm{ab}$ & $1.90 \mathrm{ab}$ \\
Sweet Charlie & $13.80 \mathrm{ab}$ & $3.75 \mathrm{ab}$ & $9.65 \mathrm{abc}$ & $1.75 \mathrm{ab}$ \\
Sweet Charlie FP & $15.95 \mathrm{ab}$ & $5.90 \mathrm{ab}$ & $11.90 \mathrm{ab}$ & $3.70 \mathrm{a}$ \\
Dover & $11.00 \mathrm{~b}$ & $3.50 \mathrm{ab}$ & $7.95 \mathrm{abc}$ & $1.90 \mathrm{ab}$ \\
Esplendida & $16.70 \mathrm{ab}$ & $3.80 \mathrm{ab}$ & $9.20 \mathrm{abc}$ & $1.85 \mathrm{ab}$ \\
IAC Guaraní & $13.10 \mathrm{ab}$ & $3.35 \mathrm{ab}$ & $8.13 \mathrm{abc}$ & $2.05 \mathrm{ab}$ \\
Yeobang & $10.70 \mathrm{~b}$ & $3.35 \mathrm{ab}$ & $4.55 \mathrm{c}$ & $1.90 \mathrm{ab}$ \\
Corea & $18.30 \mathrm{ab}$ & $4.15 \mathrm{ab}$ & $8.95 \mathrm{abc}$ & $2.10 \mathrm{ab}$ \\
Early Bright & $14.70 \mathrm{ab}$ & $4.65 \mathrm{ab}$ & $10.95 \mathrm{ab}$ & $2.65 \mathrm{ab}$ \\
Dover x Rosalinda (1) & $10.10 \mathrm{~b}$ & $2.50 \mathrm{ab}$ & $6.50 \mathrm{bc}$ & $1.55 \mathrm{ab}$ \\
Dover x Rosalinda (4) & $10.90 \mathrm{~b}$ & $3.15 \mathrm{ab}$ & $6.70 \mathrm{abc}$ & $1.21 \mathrm{~b}$ \\
Dover x R2 (63) & $13.70 \mathrm{ab}$ & $4.45 \mathrm{ab}$ & $9.45 \mathrm{abc}$ & $2.50 \mathrm{ab}$ \\
Dover x Aichi 510-28 & $11.80 \mathrm{~b}$ & $3.65 \mathrm{ab}$ & $8.50 \mathrm{abc}$ & $1.80 \mathrm{ab}$ \\
Dover x Esplendida & $10.40 \mathrm{~b}$ & $2.25 \mathrm{~b}$ & $7.50 \mathrm{abc}$ & $1.20 \mathrm{~b}$ \\
Dover x Aichi & $9.60 \mathrm{~b}$ & $2.90 \mathrm{ab}$ & $6.65 \mathrm{bc}$ & $1.65 \mathrm{ab}$ \\
Dover x Aichi 19 & $11.70 \mathrm{~b}$ & $3.00 \mathrm{ab}$ & $7.60 \mathrm{abc}$ & $2.25 \mathrm{ab}$ \\
C.V. (\%) & 17.04 & 24.41 & 17.04 & 30.18 \\
\hline
\end{tabular}

FMA = fresh mass of the aerial part; FMRS $=$ fresh mass of the root system; DMAP = dry mass of the aerial part; DMRS = dry mass of root system.

* Means followed by the same letter in the column do not differ from each other by the Tukey test at $5 \%$ probability of error. 
variables the highest mean with Sabrina. The air mass presented an average of $22.40 \mathrm{~g}$, differing from Camino Real, Dover, Yeobang, Dover $\mathrm{x}$ Rosalinda (4), Dover x Aichi 510-28, and Dover $\mathrm{x}$ Aichi 19, which produced fresh mass between $9.60 \mathrm{~g}$ and $17.70 \mathrm{~g}$, but not different from the others. The fresh mass of Sabrina's root system $(6.0 \mathrm{~g})$ is significantly higher than the Dover x Esplendida genotype $(2.25 \mathrm{~g})$. These results are superior to those found by Juárez-Rosete et al., (2020) in Chandler cultivar of $0.32 \mathrm{~g}$ of fresh stem weight in an experiment using peat as a substrate and in the evaluation 72 days after transplantation. The Festival cultivar produced daughter plants with a fresh weight of $20.5 \mathrm{~g}$, similar to that found by Rodríguez-Bautista et al., (2012) who, obtained with the same cultivate an average of $20.97 \mathrm{~g}$.

In the dry mass evaluation of the aerial part (Table 3), significant statistical differences were found, where the cultivars Sabrina and Rosalinda with $12.70 \mathrm{~g}$ were superior to Yeobang, Dover $\mathrm{x}$ Rosalinda (1) and Dover x Aichi. Sabrina and Rosalinda were among those who produced the least number of daughter plants, which may explain in some way the higher dry mass production.

Regarding the dry mass of the root system (Table 3), it was verified that the Sweet Charlie cultivar (FP) with $3.70 \mathrm{~g}$, was higher to Dover x Rosalinda (4) and Dover x Esplendida, which presented averages of 1.21 and $1.20 \mathrm{~g}$, respectively, without differing from the others. These values are superior to those mentioned by Juárez-Rosete et al., (2020), who, working with the Chandler genotype on different solid substrates, obtained daughter plants with dry root mass between 1.15 and $0.50 \mathrm{~g}$.

In this work, it was observed that the cultivar Festival dry mass of the daughter plant of $9.80 \mathrm{~g}$, greater than that reported by Rodríguez-Bautista et al., (2012) (between 5.49 and 3,33 g), in research conducted in nurseries located at different altitudes in México. Camacaro et al., (2016) have found that daughter plants with greater initial mass have produced higher fruit yield. In addition, Bartezak et al., (2010) reported that there is a positive correlation between the dry and fresh mass of daughter plants with fruit production.

\section{Conclusions}

Strawberry genotypes have genetic variability in their ability to produce daughter plants.

The Dover x Esplendida genotype has a greater production potential for daughter plants, surpassing the most planted cultivars in the country such as Dover, Sweet Charlie, and Camarosa.

The Sabrina genotype produced the highest fresh and dry mass of the aerial part and fresh mass of the root system. Sweet Charlie FP and Sabrina stood out for their high dry matter content of the root system.

The daughter plants of the evaluated genotypes were not different in leaf area, root length, and crown diameter.

The daughter plants of the different genotypes presented the minimum demanded requirements in terms of leaf numbers and crown diameter.

\section{Acknowledgments}

To the Centro de Investigación "Hernando Bertoni", dependent on the Instituto Paraguayo de Tecnología Agraria for facilitating strawberry genotypes and the experimental field to carry out this experiment. 


\section{Literature Cited}

Bartezak, M.; Lisiecka, J.; Knaflewski, M.

2010. Correlation between selected parameters of planting material and strawberry yield. Folia Horticulturae, 22(1): 9-12.

Bueno, S.C.S.

2006. Produção de mudas em ambiente protegido. In: III Simposio nacional do morango. Antunes; L.E.C.; Raseira, M.C.B. (Eds.). Pelotas: Embrapa Clima Temperado, Documentos 171). pp. 45-54.

Camarco, M.P.; Ojeda, M.; Mogollón, N.; Giménez, N. 2016. Potencial de plantas hijas de fresa cultivar Chandler de diferentes nudos de estolón como material de propagación. Unell. Cienc. Tec., 34: 1-8.

Cocco, C.; Gonçalves, M.A.; Vignolo, G. K.; Picolotto, L.;

Antunes, L.E.C.; Almeida, I.R.

2016. Produção de mudas. In: Antunes, L.E.C.; Reisser Júnior, C.; Schwengber, J.E. (Eds.). Morangueiro. Embrapa Brasilia D F. pp. 79-109.

Cocco, C.; Andriolo, J.L.; Erpen, L.; Cardoso, L.; Casagrande, G.S. 2010. Development and fruit yield of strawberry plants as affected by crown diameter and plantlet growing period. Pesq. agrop. bras., 45(7): 730-736.

Dias, M.S.C.; Pereita, M.G.N.; Reis, J.B.R.S.; Jesus, A.M.;

Oliveira Junior, J.L.; Padua, J.G.

2014. Produção de mudas de morangueiro em cultivo suspenso sob ambiente protegido. Horticultura Brasileira, 31(2): 153-160. Suplemento CD Rom julio 2014.

Cordeiro, E.C.N.; Resende, J.T.V.; Saggin Junior, O.J.; Nascimento, D.A.; Zeist, A.R.; Favaro, R.; Córdova, K.R.V.; Gabriel, A.

2019. Fisiologia da produção de morangueiros inoculados com fungos micorrízicos arbusculares. Semina: Ciências Agrárias, 40(6): 3333-3344.

Durner, E.F.; Poling, E.B.; Maas, J.L.

2002. Recent avances in strawbery plug trasplant technology. HortTechnology, 12(4): 545-550.

FAO (Food and Agricultura Organization).

2018. Estimación de la producción mundial de fresa. FAOSTAT. Available at: http://www.fao.org/faostat/ es/\#data/QC. Accessed: 10/Feb/2020.

Gonçalves, M.A.; Cocco, C.; Picoloto, L.; Vignolo, G.K.; Antunes, L.E.C.

2012. Diâmetro de coroa e presença de folhas na produção de mudas de morangueiro. Libro de Resúmenes XXII Congresso Brasileiro de Fruticultura. Bento Gonçalves. Rio Grande do Sul. Brasil. p. 5402-5405.

Hochmuth, G.; Cantliffe, D.; Chandler, C.; Stanley, C.; Bisch, E.; Waldo, E.; Legard, D.; Duval, J.

2006. Containerized strawbery trasplants reduce establishment period, water use and enhance early growth and flowering compared with bare-roots plants. HorTechnology. 16(1): 46-54.

Ishijima, T.; Okwara, Y.

2002. Manual de técnicas de cultivo de hortalizas de fruta (tomate - melón - frutilla). Ministerio de Agricultura y
Ganadería. Agencia de Cooperación Internacional de Japón. Caacupé, Paraguay. 240 p.

Juárez-Rosete, C.R.; Aguilar-Castillo, J.A.; Bugarín Montoya, R.; Aburto-González, C.A.; Alejo-Santiago, C.

2020. Medios de enraizamiento y aplicación de auxinas, en la producción de plántulas de fresa. Ciencia y Tecnología Agropecuaria. 21(1), e1319.

Massetani, F.; Ganagatharan, R.; Neri, D.

2011. Plant architecture of strawberry in relation to abiotic stress, nutrient application and tipe of propagation system. Genes, Genomes and Genomics, 5(1): 12-23.

Menzel, C.M.; Smith, L.

2012. Effect of time of planting size on the productivity of "Festival" and "Florida Fortuna" strawbery plants in a subtropical environment. HorTechnology, 22(3): 330-337.

Oliveira, R.P. de; Braham, R.D.; Scivittaro, W.B.

2007. Produção de mudas de morangueiro em casa-devegetação utilizando recipientes suspensos. Horticultura Brasileira, 25 (1): 107-109.

Oliveira, R.P.; Scivittaro, W.B.

2009. Produção de frutos de morango em função de diferentes períodos de vernalização das mudas. Horticultura Brasileira, 27(1): 91-95.

Oliveira, C.S.; Cocco, C.; Andriolo, J.L.; Bisognin, D.A.; Erpen, L.; Franquez, G.G.

2010. Produção e qualidade de propágulos de morangueiro em diferentes concentrações de nitrogênio no cultivo sem solo. Revista Ceres, 57(4): 554-559.

Rodríguez-Bautista, G.; Calderón-Závala, G.; Jaen-Contreras,

D.; Curiel-Rodríguez, A.

2012. Capacidad de propagación y calidad de planta de variedades mexicanas e importadas de fresa. Revista Chapingo Serie Horticultura, 18(1): 113-123.

Rosa, H.T.; Streck, N.A.; Walter, L.C.; Andriolo, J.L.; Silva, M.R. 2013. Crescimento vegetative e productive de duas cultivares de morango sob epocas de plantio em ambiente subtropical. Ciência Agronômica, 44(3): 604-613.

Serçe, S.; Hancock, J.F.

2005. The temperature and photoperiod regulation of flowering and runnering in the strawberries, Fragaria chiloensis, $F$. virginiana, and $F$. $x$ ananassa. Scientia Horticulturae, 103: 167-177.

Silva, A.F.; Dias, M.S.C.; Maro, L.A.C.

2007. Botânica e fisiologia do morangueiro. Informe Agropecuario, 28(236): 7-13.

Verdial, M.F.; Tessarioli Neto, J.; Minami, K., Scarpare Filho,

J.A.; Christoffoleti. P.J.; Scarpare, F.V.; Barela, J.F.; Aguila,

J.S.; Kluge, R.A.

2009. Fisiología de mudas de morangueiro produzidas em sistema convencional e em vasos suspensos. Revista Brasileira de Fruticultura, 31(2): 524-531.

Tessarioli Neto, J.; Ortigoza, L.E.R.; Verdial, M.F.

2003. Produção de mudas de cultivares de morangueiro em duas épocas de coleta. Horticultura Brasileira, 21(2): 231-233. 
